\section{A TECHNOLOGIST LOOKS AT THE FUTURE}

$\mathrm{T}$ HE address delivered by Dr. C. R. Burch on the occasion of the presentation to him on April 9 of the nineteenth Duddell Medal of the Physical Society took the form of an outline account of certain advances in physical technology in which he has taken part, set out with the view of demonstrating some of the circumstances and conditions which made those developments possible.

"These may perhaps illustrate the kind of conditions that we have to establish in the future, if we want good technological progress to be madein Great Britain. And it is vitally important that we should stand in the technical forefront-at least as important in the coming peace as in the war. Here is something we cannot afford to neglect: whether we like it or not, whether the politicians like it or not, technical progress, more than any other controllable factor, is reshaping our brave new world. We have to produce a contribution at least as constructive as that of our Allies: if we fail in that, we shall not keep their respect, and if we do not keep their respect we shall certainly lose their alliance."

Dr. Burch's story opened about twenty years ago, in Metropolitan-Vickers, when Dr. T. E. Allibone was working on the preparation of zirconium as the basis of a long-term programme devised by Dr. A. P. M. Fleming. Zirconium was known in powder form, and the investigation aimed at producing it in coherent metallic form, with the view of examining its properties. The question of industrial use was a dim prospect; the immediate task was to gather knowledge. It was decided to try the induction furnace, and it proved successful; but so far as could be seen at the time, neither the metal itself nor alloys of it were of any commercial value. Nevertheless, the effort had not been wasted time, for it had produced a team of three men, Allibone, Burch and Ryland Davis, who had gained considerable knowledge and experience of vacuum work, highfrequency technique and the application of H.F. currents and induction heating, together with "some. thing of the artist's sense of enjoyment, emotional drive, call it what you will, that arises from widening the range of one's experimental inquiry".

Ryland Davis and Burch continued with the development of induction furnaces, leading to a t-ton furnace which would melt brass or copper at 50 cycles or steel at 500 cycles in place of the million cycles necessary in their earlier furnaces.

"The coil for this furnace was about the size of a small dustbin-a coil of one layer of 1 in. $x \frac{s}{10}$ in. copper strap, wound on 'high edge'; 130 turns of it in a length of $24 \mathrm{in}$. or so. It had to be watercooled on the outer edge of each turn, so as to leave a radial thickness of 1 in. of solid copper on the inside of the coil. The Transformer Department wound the coil for us. But we had to tackle the watercooling ourselves. This we did by adapting a device called a 'mica undercutter' to mill a semicircular groove round the outside of the coil, and in the groove we soldered sixty lengths of $\frac{1}{8}$ in. copper tube-a total of about 200 yards of it, providing sixty separate inlets and outlets so that enough cooling water could be got through the coil to remove the $30 \mathrm{~kW}$. resistance-loss that occurred in it, when it was used on brass, or the rather smaller loss which occurs in it when it is used on steel. I should like to record our thanks to Mr. Hutchinson, now of Sir George Thomson's staff, who helped us solder that interminable joint. I do not say that coil was a thing of beauty. But it did its two-fold job. Here may I touch once more on the future?

"Let us do all in our power to make it possible for the embryo physicist of the future to satisfy fully any desire he may have to acquire knowledge of crafts and skill in the use of tools. I cannot assess too highly in this respect the education I received at Oundle School. I use deliberately the phrase 'education' in the use of tools rather than 'training' because again and again I have been struck by the extent to which such craftsmanship and manual skill as I possess has helped me to form happy personal relations rapidly with all sorts and conditions of men. As that is an extremely important part of life, I am not going to apologize for digressing into a brief analysis of the operative factors. On the conscious level, the existence of a common manual skill or craftsmanship provides a link of mutual respect, and mutual respect is almost invariably an essential prerequisite to friendship. On the unconscious, or as some psychologists prefer, unwitting levels, the acquisition of a similar craftsmanship provides a number of similar links between ideas, and, what is far more important, similar links between ideas and emotions, so that similar emotions are the more readily aroused, and similar ideas the more readily 'intuited'--in short, the two men are the more readily in sympathy. Of course, if the skill has been acquired reluctantly under compulsion, any related idea is the more likely to arouse the emotion of hostility, and the idea of hostility, and even, at a higher level of mental integration, something far worse - the ideal of hostility. For that reason I would not for one moment advocate imposing in the sacred name of education compulsory courses in workshop practice for all and sundry, or even for all physicists. No ! That isn't my 'ideal' at all. Rather would I see courses of this type run simply for such as care to attend.

"I should like to touch on two other aspects of the value of work with one's own hands. First, in design : in my experience it has only been physicists who do not make their own apparatus who have been apt to persist in designing things that are quite incredibly difficult and expensive to make-difficult out of all proportion to the very small gain associated with the design in question. When you explain this to them, they see the point, and not without a certain bitterness do they complain that they must keep $a^{*}$ conscious and exhausting watch for pitfalls of construction which those 'educated' in the use of tools very largely ayoid as it were unconsciously and reflexly, by sympathy."

The 500-cycle t-ton steel furnace being made, it had to be shown that it could be used to make alloy steels. In the face of the scepticism of practical steel-makers, the difficulties of 'teeming' the molten steel were overcome, and the 'electric fountain' effect, due to the magnetic field of the coil acting on the eddy currents in the molten charge and causing the metal to well up in the centre and run down at the sides, was found not to distribute small particles of slag through the metal. All this took more than a year to accomplish, and useful information on 'chilling' and 'burning' of cast motal was obtained.

Dr. Burch emphasized here that although Ryland Davis and he made part of the first $\frac{1}{4}$-ton furnace with their own hands, and supplied in some measure. 
inspiration and technical leadership, the development, even at this stage, had only been possible by the co-operation of many others in the Research Department and in other parts of MetropolitanVickers. By 1934 there was installed in Sheffield a total induction-furnace capacity of 13 tons of furnaces capable of simultaneous running, and $6,000 \mathrm{~kW}$. of generators. By 1939 this had risen to 38 tons and $16,000 \mathrm{~kW}$. of generators. As the power consumption is about $600 \mathrm{kWh}$. per ton, this means that in 1939 Sheffield could turn out 600 tons per day of induction furnace steel.

"Thus the part played by Ryland Davis and myself, building on the foundations laid by Northrup and others, is itself already in some sense out of date, and is but another foundation on which a younger generation is building; and that, some say, that transitory and ephemeral aspect of technological achievement, is just what deprives it of cultural value or spiritual satisfaction. I cannot agree with that view at all. For it is the special glory of our science and its applications that the more it changes, the more it is the same thing. I am sure that all who have taken part in any technological development will have found as a concomitant of achievement a fuller realization of the underlying unity of past and present, and a lasting satisfaction of the kind that can endow even tragedy with triumph. These are matters not capable of precise definition, but expressible only in terms of mysticism and of poetry. When the subject is technology, one turns naturally to Kipling - may I remind you of his poem 'The Palace', in 'The Five Nations' ?"

In the second part of his address, Dr. Burch turned to other of the end-results of Dr. Allibone's work on zirconium and its alloys. The Process and Insulation Department of Metropolitan-Vickers wanted to try the effect of a really good vacuum on the process of impregnating porous insulating materials with transformer oil, with the view of increasing the dielectric strength. One difficulty was that the impregnator had to work in a steam-jacket. The problem re-awoke in Dr. Burch an interest in distillation as a process worth experimenting with; in particular, vacuum distillation, if approached from the kinetic theory aspect, seemed promising, as a means of distilling substances which had not hitherto been distilled.

Accordingly, Burch, in association with Watts and Bancroft, constructed a vacuum still in which the condensing surface took the form of a cooled roof immediately above the evaporating pool of liquid, so that rate of distillation is limited only by rate of vapour creation. There was something of the 'heads-I-win, tails-you-lose' about the experiment, for either substances would distil in this still (and that would be useful in chemistry), or else they would not (and hence had very small vapour pressure and would be useful as sealing compounds for vacuum joints). After using the still for a week or so, the fascinating idea came to Dr. Burch that, since lubricating oil distilled in this still at temperatures $100^{\circ} \mathrm{C}$. or so higher than that required for mereury, it might replace mercury in a condensation pump, and so dispense with $100^{\circ} \mathrm{C}$. of artificial refrigeration in making high vacua. This made possible high-power demountable valves and X-ray tubes.

"So once more there were developments involving the co-operation of a great number of people. Dr. Allibone decided to develop domountable X-ray tubes, and eventually made the million-volt tube of the
High-Voltage Department of St. Bartholomew's Hospital : Mr. Baneroft, Mr. Preece and Mr. Burrows made the pumps and the continuous vacuum still to make the oil for the pumps, and the vacuum still with which Carr and Jewell of British Drug Houses first distilled vitamin A-for a wider group is involved than simply that of Metrovick. Further, we were not the only team to experiment with molecular distillation. While we were making our first still, and quite independently, Dr. K. C. D. Hickman of the Eastman Kodak Co. in Rochester, N.Y., was tackling similar problems in very much the same way. Other teams from British Drug Houses, Imperial Chemical Industries, Shell-Mex and the Bataafsche Petroleoum Mij. also co-operated in the development of application of molecular distillation.

"Returning to my own special interest-valves: I made demountable 3 -electrode valves, while my brother developed a $30 \mathrm{~kW}$. demountable 4-electrode valve, which was so far as I know the first screengrid valve of that power made in Great Britain. I should like to acknowledge our great debt to our colleagues in this work, Mr. Ludlow, Mr. Phillips, Dr. Sykes, until his translation to the National Physical Laboratory, and Dr. Dodds: if it was our privilege in the beginning to have given in some measure inspiration, it was their collaboration that made the development successful, and their inspiration that has carried it on. I should like also to express our gratitude to the radio staff of the General Post Office for their unfailing co-operation during the 'teething' troubles of demountable valves in the Rugby radio station.

"I have spoken of the co-operation of a team. But what of the man behind the team? Here I should like to say specifically : All that my colleagues and $I$ at Metropolitan-Vickers have achieved in this work, we owe ultimately to Dr. A. P. M. Fleming. That raises the question : What of the future? How shall we choose men to do the kind of job that Dr. Fleming is doing ?

"I do not believe that a scientific man keenly interested in personal research is likely to be the best man to choose for that kind of administrative work, because' his emotions will in general be too firmly linked with his personal research, and he will find it too difficult to dissociate these emotions in making judgments on points of policy. I think that a scientific man who has ceased to be interested in personal research may well develop the qualities needed for deciding questions of policy in long-term research, especially if he retains or acquires an interest in the personalities of research workers, for I have the strong impression that the question of whether a particular line of work will or will not provo fruitful for a given organization may often be determinable less by logical than by psychological considerations. But, above all, avoid appointing a 'man of mature judgment'and that phrase I take to imply a man whose judgments are determined entirely by his emotions: whose emotions are keyed indissolubly to the events of his remote past, and who is totally unreceptive to new ideas except in so far as they may arouse fortuitously the emotions belonging to a bygone age.

"I have touched on the psychology of the research worker, and that brings me to the question, What are the factors which determine whether a man shall be likely to have original ideas on a given subject, and be keen to work on it ? For a knowledge of these factors may well influence our policy in the education of research workers. I have just one suggestion to 
make : it is that at any rate for an appreciable percentage of researchers-I do not say for them allwe have to do with a factor which the psychologists like to refer to in German (possibly because it is so marked a characteristic of the German nation): a Wiederholungsdrang: a repetition urge : a tendency to repeat patterns in life. I would suggest, then, that scientific or technological researches tend to be in some sense grown-up variants of some more youthful form of activity. If this is so, to find the ultimate foundations of success in research, we may well have to go back beyond the university-to the public school, or even to the preparatory school. Here I should like to acknowledge once more the very great debt that I owe to Oundle School, particularly in that they let me experiment with the small-scale semi-technical distillation of coal tar, because I wanted to. Coal tar at atmospheric pressure, 1918 : oil in a vacuum, 1928 !

"What of education in the future? I look on it as an important indirect contribution to our long-term research policy to provide in our schools facilities for the keenest, at any rate, to follow up almost whatever kind of extra-curricular activity may strike their interest-and this without binding themselves in any way as to their future careers. This foretaste of achievement in following up individual interest provides, I believe, the strongest possible stimulus to education, and if the nature of the interest should change, the stimulus remains the same. 'The cultivation of enthusiasm $I$ take to form the first requisite in that far-sighted educational policy and that courageous long-term research policy to which I look forward in the future, after the War."

\section{AGRICULTURAL DEVELOPMENTS IN THE U.S.S.R." By SIR JOHN RUSSELL, F.R.S.}

$\mathrm{P}$ RIOR to the Revolution three systems of farming were practised in the U.S.S.R. : (1) large estates; (2) small peasant farms ; (3) peasant land farmed by the peasants under the $M i r$, the village council or commune of very ancient origin.

Some of the large estates were run on good modern lines, some were put into the hands of managers whose business it was to extract all they could for the owner, others were moderately well managed. The peasant farms were small holdings owned by the individual farmers, which had resulted from the various agrarian reforms, the most important of the later ones being those of Stolypin (1905), who had a Danish adviser and was aiming at the Danish model. The peasant land under the commune (nadiel land) belonged to the body of peasants but not to any individuals; it was parcelled out into many strips which were periodically distributed by the Mir among the peasants in accordance with the size of family, etc. These strips were scattered over the whole area so that each man should have his share of good and of bad soil. In the time of the Revolution it was estimated that about 45 per cent of the cultivated land was in the hands of the peasants.

All three systems were disliked by the Bolsheviks, the first two because they involved private ownership of land, and the third because of its grave inefficiency "Substance of a lecture at the Central Council for Health Education
Summer School held in London during August. and the utter impossibility of introducing modern improvements. The Bolsheviks also disliked the peasant mentality, so utterly different from that of the factory worker. The peasant wanted to sell his products at high prices while the factory worker wanted to buy them cheaply. The factory worker was accustomed to work in masses for an employer, and had before the Revolution no sense of proprietorship : the peasant was used to working alone or in small groups and always felt that he owned the land he tilled.

After some experiments, State farms were set up which accorded well with Bolshevik theory. The peasants were employees of the State receiving a weekly wage, living in great blocks of dwellings in a central area developed like a town. The whole organization resembled that of a factory, and it was expected that the peasants would develop the factory workers' outlook and become one with them. But the peasants did not like them and so they never developed: in 1938 only about 10 per cent. of the cultivated land was worked as State farms, and they were used for special purposes. A completely different type of farm was set up, on the basis of the old Mir. The first were communes in which the whole body of workers was responsible for the full maintenance of each individual family; but this did not answer. The artel organization was therefore adopted : another old Russian method which has no English equivalent. In this the workers feed and house themselves but the produce belongs to them, and after all outgoings have been met the balance is distributed according to the work done. The workers are paid in actual produce : mostly grain, potatoes, and vegetables, these being the main constituents of the peasants' dietary ; usually also there is hay for the workers' animals, and a small amount of cash. This method after suitable modification proved, much more acceptable, and by 1939 a very large part of the cultivated land of the U.S.S.R. was farmed in this way.

The farms were called 'Collectives'. All the cultivated land in the village, whatever its previous ownership, was thrown into one big farm : it might be $1,000-4,000$ acres or more, but was not usually unmanageable in size. All the peasants of the village could come into the group, but preference was given to the so-called 'poor peasants'. The plan of production was until just before the War sent from headquarters: it had been discussed during its development, but once settled, it could not be further discussed. The workers elected a committee to carry it out and to allocate the tasks to the different people; the chairman, however, was not freely elected as he had to be accepted by the Party and the Government; he often came from outside and did not usually stay long. The Party always insisted on keeping its hold on the farms, and it had its representative, who was quite independent of the committee.

Payment was always by the piece; a certain job of work was called a "labour day", and when a man had done this he was credited with one day's work. Not infrequently about two hundred would be done during the year, but specially good workers would put in many more. The worker could eat his share of the produce or sell it to the farm, the Co-operative or in the peasant market.

'The workers' share of the produce varied with the yields and the outgoings. 'The Government's share has varied. For some time prior to 1939 it was a fixed amount per acre of winter grain sown, and of 